\title{
İşletmeler İçin Turizm Yatırım Potansiyelinin Belirlenmesi: Kırgızistan Örneği (Determination of Tourism Potential for Business: Example of Kyrgyzstan)
}

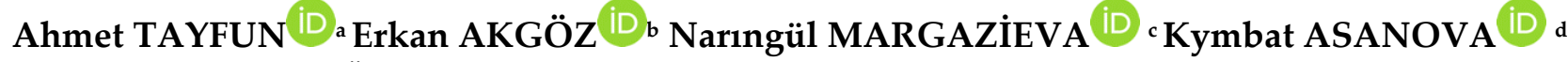 \\ a Kırgızistan-Türkiye Manas Üniversitesi, Bişkek, Kırgızistan. ahmet.tayfun@manas.edu.kg \\ b Kırgızistan-Türkiye Manas Üniversitesi, Bişkek, Kırgızistan. erkan.akgoz@manas.edu.kg \\ c Kırgızistan-Türkiye Manas Üniversitesi, Bişkek, Kırgızistan. naryngul.margazieva@manas.edu.kg \\ d Kırgızistan-Türkiye Manas Üniversitesi, Bişkek, Kırgızistan. kymbat.asanova@manas.edu.kg
}

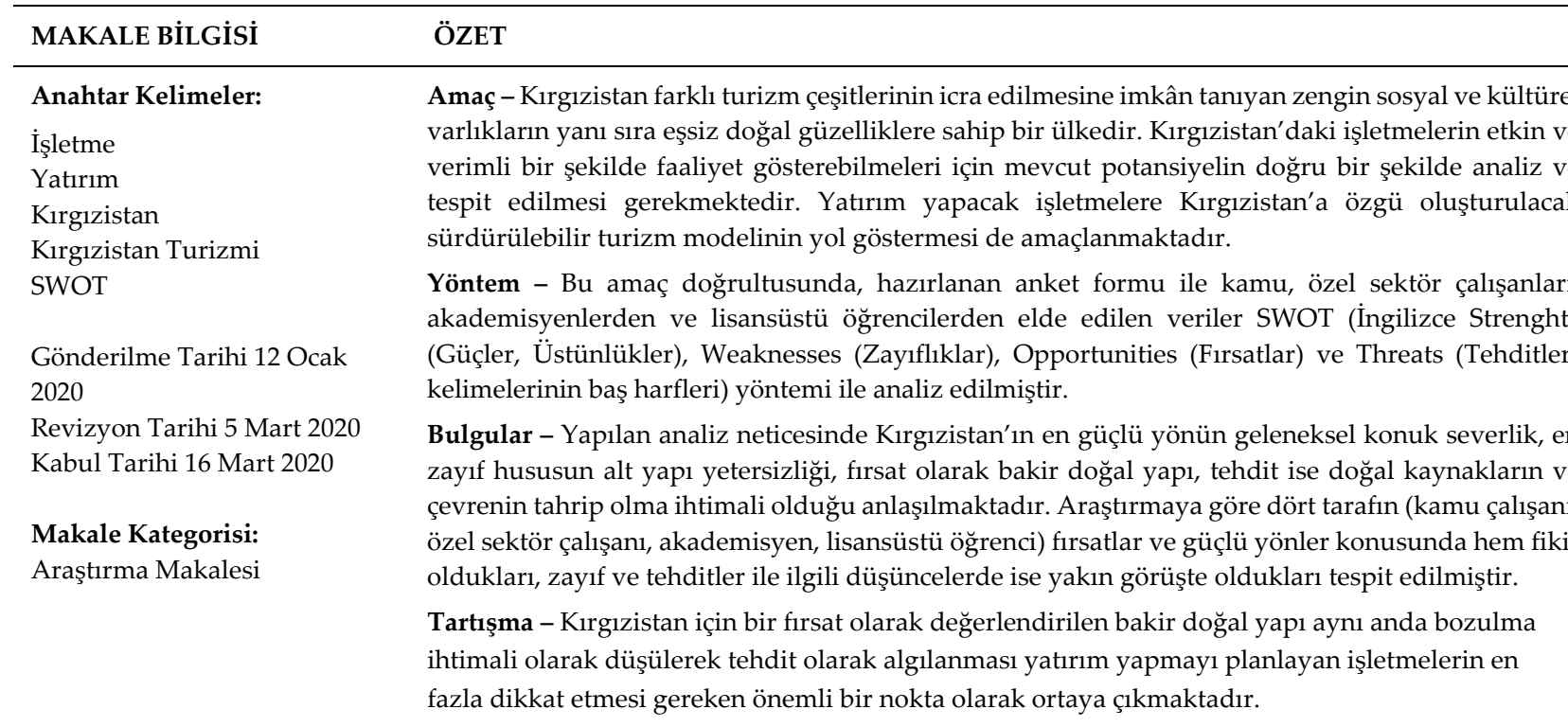

\begin{tabular}{|c|c|}
\hline ARTICLE INFO & ABSTRACT \\
\hline $\begin{array}{l}\text { Received } 12 \text { January } 2020 \\
\text { Revised } 5 \text { March } 2020 \\
\text { Accepted } 16 \text { March } 2020 \\
\text { Article Classification: } \\
\text { Research Article }\end{array}$ & $\begin{array}{l}\text { Purpose - Kyrgyzstan is a country with rich natural and social assets, as well as unique natural } \\
\text { beauties, that allow the execution of different types of tourism. For businesses in Kyrgyzstan to } \\
\text { operate effectively and efficiently, the current potential needs to be analyzed and determined } \\
\text { accurately. It is also aimed to guide the sustainable tourism model to be created specifically to } \\
\text { Kyrgyzstan for the companies that will invest. } \\
\text { Design/methodology/approach - For this purpose, the data is obtained from public, private sector } \\
\text { employees, academicians and graduate students by the questionnaire. It was analysed with SWOT } \\
\text { (Strengths, Weaknesses, Opportunities, and Threats) method. } \\
\text { Findings - As a result of the analysis, it is understood that the strongest aspect of Kyrgyzstan is } \\
\text { traditional guest loving, the weakest point is the infrastructural deficiency, the opportunity is the } \\
\text { virgin natural structure, the threat is the possibility of destruction of natural resources and the } \\
\text { environment. According to the research, it was determined that four parties (public employee, } \\
\text { private sector employee, academician, graduate student) both had an idea about opportunities and } \\
\text { strengths, and had a close opinion about weak and threats. } \\
\text { Discussion - The fact that virgin natural structure, which is considered as an opportunity for } \\
\text { Kyrgyzstan, is considered as a threat at the same time appears as an important point that the } \\
\text { companies planning to invest should pay attention to. }\end{array}$ \\
\hline
\end{tabular}

\section{Önerilen Atıf/ Suggested Citation}

Tayfun, A., Akgöz, E., Margazieva, N., Asanova, K. (2020). İşletmeler İçin Turizm Yatırım Potansiyelinin Belirlenmesi: Kırgızistan Örneği, İşletme Araştırmaları Dergisi, 12 (1), 693-704. 


\section{Giriş}

Dünyada turizm endüstrisinin hızlı büyümesi, toplumun refahı ve çevre üzerindeki etkisiyle birlikte diğer sektörlerin de gelişmesine katkı sağlamaktadır. Bu husus dikkate alındığında, turizm sektörünün Kırgızistan'da da öncelikli sektörlerden biri olması arzulanmaktadır.

Kırgızistan doğal varlıkları, tarihi-kültürel yapısı ile önemli turizm potansiyeline sahip olmasına rağmen, turizm sektörü henüz ülke ekonomisine arzulanan katkıyı sağlayamamaktadır. Ülke, turizm çeşitliliği anlaminda önemli bir zenginliğe sahiptir. Geleneksel tatil ve dinlenme (3S turizmi) amaçlı seyahat eden turistler için Isık Göl bölgesi; kültür turizmi kapsamında Süleyman Dağı ve Taş-Rabat; eko turizm potansiyeli için muhteşem bir doğaya sahip Sarı Çelek ve Son-Göl; kış turizm olanakları için Karakol; dünyanın en büyük ceviz ormanları ile kaplıca tesislerine ev sahipliği yapan Calal-Abad ülkede akla ilk gelen destinasyonlardır (Erdem vd, 2015).

Turizm sektörü, Kırgızistan ekonomisinin öncelikli ve ihracata yönelik sektörlerinden biri olarak belirlenmiştir. Bu kapsamda Kırgızistan Hükümeti'nin 2019-2023 yılları için hazırlamış olduğu "Sürdürülebilir Turizmi Geliştirme Programı" onaylanmıştır (http://deptourism.gov.kg/программаразвития-туризма-до-2020-года/). Söz konusu program turizm alanındaki mevcut dünya turizm eğilimlerini ışığında ülkenin turizm sektöründeki mevcut durumu yansıtmakta ve geleceğe yönelik planları içermektedir.

\section{Turizm Sektörü Açısından Kırgızistan}

Bağımsız Türk Cumhuriyetlerinden biri olan Kırgızistan, Orta Asya'nın kuzeydoğusunda bulunmakta, batıda Özbekistan, kuzeyde Kazakistan, güneybatıda Tacikistan, güneydoğuda ise Çin ile komşudur. Kırgızistan Batken, Calal-Abad, Çüy, Isık-Göl, Narın, Oş ve Talas olmak üzere 7 bölgeden oluşmaktadır. Başkenti-Bişkek şehridir. Dili Kırgız Türkçesidir. Ayrıca ülkede Rusça da resmi dil statüsüne sahiptir.

Kırgızistan'ın bakir doğası, turistleri ülkeye çeken önemli arz kaynaklarındandır. Ülke 1923 göl ve 3500'den fazla büyük ve küçük nehirlere (Kırgız Cumhuriyeti Milli İstatistik Komitesi, 2018), 90'dan fazla hayvan ve 6.300 bitki türüne sahiptir (Milli Çevre Raporu, 2016: 107). Dünyanın en yüksek rakıma sahip gölleri olan IsıkGöl, Son-Göl, Çatır-Göl ve Sarı Çelek Kırgızistan'da bulunmaktadır. Ayrıca, ülke Orta Asya'nın büyük bir bölümünü besleyen Narın Nehri'nin en büyük su arterine sahiptir.

Ülkenin \%90'ını dağlar oluşturmaktadır. Buna ek olarak ülkede en yüksek dağ zirvelerinden olan, yüksekliği deniz seviyesinden 7000 metreyi aşan Ceniş, Lenin ve Han Tengri Zirveleri macera sevenleri kendine çekmektedir.

\section{Kirgızistan Turizmine Ait Verileri}

Tablo 1: Kırgızistan'1 Ziyaret Eden Yabancıların Sayısı

\begin{tabular}{|l|r|r|r|r|r|}
\hline & $\mathbf{2 0 1 4}$ & $\mathbf{2 0 1 5}$ & $\mathbf{2 0 1 6}$ & $\mathbf{2 0 1 7}$ & $\mathbf{2 0 1 8}$ \\
\hline Toplam & $\mathbf{4 , 4 1 8 . 6}$ & $\mathbf{4 , 3 3 5 . 2}$ & $\mathbf{4 , 1 4 7 . 4}$ & $\mathbf{4 , 6 6 6 . 5}$ & $\mathbf{7 , 0 5 7 . 1}$ \\
\hline BDT (Kazakistan, Özbekistan, Rusya vd. ülkeler) & $4,223.4$ & $4,156.1$ & $3,909.8$ & $4,408.6$ & $6,771.0$ \\
\hline BDT (dışındaki ülkeler Çin, Türkiye, Hindistan) & 195.2 & 179.1 & 237.6 & 257.9 & 286.1 \\
\hline
\end{tabular}

Kaynak: Kırg1zistan Milli İstatistik Kurumu

Kırgızistan Devlet Sınır Hizmeti verilerine göre 2018 yılında sınırdan geçen yabancıların sayısı 7 milyonu aşmıştır (Tablo 1). Ülkeyi ziyaret eden yabancıların önemli kısmı Kazakistan $(2,690.8)$, Özbekistan (3,363.7 ), Rusya (507.9) ve Tacikistan (182.5) vatandaşları olmak üzere BDT ülkelerinden gelmektedir. Kırgızistan'a turist gönderen ülkeler arasında ilk sırayı 2017 yılına kadar Rusya ve Kazakistan oluşturmaktadır. Bir takım siyasi değişiklikler ve ülkeler arasında sınır geçişlerinin kolaylaşması, 2017 yılından sonra Özbekistan'ı ilk sıralara getirmiştir. BDT dışında turist gönderen ülkeler incelendiğinde Türkiye (69.3), Çin (36.0), Hindistan (26.0) ve Almanya (22.7) gibi ülkelerin sıralandığı görülmektedir (www.stat.kg). Yukarıda da belirtildiği gibi, veriler sınır kapısından geçen toplam yabancı sayısını göstermekte olup, turizm ile ilgili istatistiki bilgilerin henüz net olmadığı anlaşılmaktadır.

Kırgızistan Turizm Bakanlığı verilerine göre ülkeye gelen turist sayısının artmasına Dünya Göçebe Oyunları önemli katkı sağlamıştır. Forbes, Global Spots 2013, Dünya Seyahat ve Turizm Konseyi, Coğrafi Seyahat 
A. Tayfun - E. Akgöz - N. Margazieva - K. Asanova 12/1 (2020) 693-704

Ödülleri, National Geographic Gezgini, National Geographic, Financial Times, The Guardian Dünya Göçebe Oyunlarına büyük önem vermiştir. Buna ek olarak, uluslararası yayınevleri The Guardian ve Lonely Planet tarafından 2019 yılında ziyaret etmek için tavsiye edilen dünyanın en iyi 10 ülkesi arasında Kırgızistan'ı da göstermektedir. Tüm bu gelişmeler, Orta Asya'da kendisini bir turizm ülkesi olarak tanımlayan Kırgızistan'ın olumlu bir imaja sahip olmasına vesile olmuştur.

Ülkenin 2018 yılı turizm gelirleri 453.4 milyon ABD doları olarak gerçekleşmiştir. Elde edilen gelirlerin 386,8 milyon ABD doları - BDT ülkelerinden, 66.6 ABD doları ise BDT dışındaki ülkelerden elde edilmiştir (www.stat.kg).

Turizm gelirlerinin GSYİH'ya olan katkısı yıllar itibariyle artış göstermektedir. Sürdürülebilir Turizm Geliştirme Planında 2019 yılı \% 5,3, 2020 yılı \% 5,6, 2021 yılı \% 6,0 ve 2022 yılı \% 6,5 olmak üzere 2023 yılına turizm sektörünün GSYİH'ya olan katkısının \% 7'ye ulaşması hedeflenmektedir(www.stat.kg).

Tablo 2: Yıllar İtibariyle Kırgızistan’daki Turizm İşletmelerinin Sayısı

\begin{tabular}{|l|r|r|r|r|r|}
\hline & $\mathbf{2 0 1 5}$ & $\mathbf{2 0 1 6}$ & $\mathbf{2 0 1 7}$ & $\mathbf{2 0 1 8}$ & $\mathbf{2 0 1 9}$ \\
\hline Toplam & $\mathbf{9 , 5 2 4}$ & $\mathbf{1 0 , 3 0 6}$ & $\mathbf{1 1 , 0 1 2}$ & $\mathbf{1 1 , 7 1 5}$ & $\mathbf{1 2 , 6 1 5}$ \\
\hline Oteller & 966 & 1,075 & 1,137 & 1,220 & 1,287 \\
\hline Turizm ve Dinlenme Tesisleri & 843 & 877 & 918 & 967 & 1,047 \\
\hline Restoranlar & 4,306 & 4,744 & 5,112 & 5,438 & 5,858 \\
\hline Seyahat Acenteleri ve Tur operatörler & 3,300 & 3,502 & 3,732 & 3,968 & 4,298 \\
\hline Sanatoryum ve Kurort İşletmeleri & 90 & 89 & 94 & 100 & 103 \\
\hline Koruma Altına Alınmiş Alanlar ve Milli Parklar & 19 & 19 & 19 & 22 & 22 \\
\hline
\end{tabular}

Kaynak: www.stat.kg

Tablo 2' de görüldüğü gibi genel olarak turizm işletmelerin sayısı artmaktadır. 2015 yılına kıyasla 2018 yılında otellerin sayısı $\% 25$, turizm ve dinlenme tesislerinin sayıs $\% 19$, restoranların sayıs1 $\% 26$, seyahat acentaları ve tur operatörlerin sayısı \% 23, sanatoryum ve kurort işletmeleri ile koruma altına alınmış alanlar ve milli parkların sayısı \% 13 artmıştır. Sanatoryum, Latincede tedavi etmek ve iyileştirmek anlamına gelen 'sanare' kelimesinden türemiştir. Tıp ansiklopedisine göre ise; genelde şifalı doğal kaynakların yanı sıra fizyoterapi, özel rejim, diyet ve egzersizler ile tedavi yapan tıbbi kuruma alanları olarak tanımlanmaktadır (https://dic.academic.ru/).

Kurort kelimesi ise finans sözlüğü ve modern ansiklopediye göre Almanca bir kelime olup, tedavi yeri (kur "tedavi", ort "yer") anlamına gelmektedir. Kurort - korumaya alınan ve tedavi özellikleri keşfedilen doğal kaynaklarından en az biri (su, çamur, iklim vs.) bulunan, gelen insanların dinlenme ve tedavi ihtiyaçlarını karşılamak için alt yapısı geliştirilen özel alandır (https://dic.academic.ru/). Kırgızistan'ın coğrafi yapısı kurort ve sanatoryumlar için oldukça elverişli olduğundan, Sovyet Birliği zamanında bu alanda pek çok yatırım yapılmıştır. Özellikle Isık-Göl bölgesi astronotların rehabilitasyonu için uygun bir destinasyon olarak tercih edilmiştir. Ancak, Kırgızistan bağımsızlığını ilan ettikten sonra devlete ait sanatoryum, kurort, milli parklar ve koruma altına alınmış alanlara yatırımlar yapılmamıştır. Söz konusu yatırımların yetersizliği aşağıdaki Tablo 2'de daha net fark edilmektedir. 
A. Tayfun - E. Akgöz - N. Margazieva - K. Asanova 12/1 (2020) 693-704

Tablo 3. Turizm İşletmelerinin Bölgelere Göre Dağılımı (2018 yılı)

\begin{tabular}{|c|c|c|c|c|c|c|c|}
\hline & $\frac{\ddot{0}}{\overline{0}}$ & 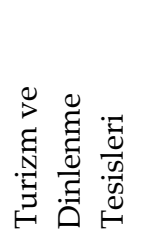 & 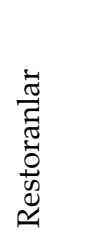 & 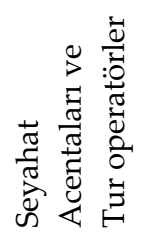 & 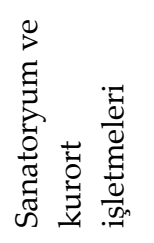 & 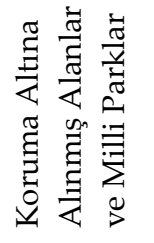 & 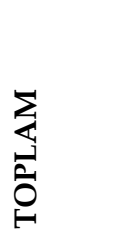 \\
\hline Toplam & 1,287 & 1,047 & 5,858 & 4,298 & 103 & 22 & 12615 \\
\hline Batken bölgesi & 49 & 25 & 608 & 65 & 4 & 3 & 754 \\
\hline Calal-Abad bölgesi & 121 & 70 & 603 & 204 & 9 & 6 & 1013 \\
\hline Isık-Göl bölgesi & 283 & 518 & 612 & 344 & 30 & 3 & 1790 \\
\hline Narın bölgesi & 88 & 117 & 159 & 81 & 2 & 3 & 450 \\
\hline Oş bölgesi & 47 & 35 & 653 & 131 & 7 & 3 & 876 \\
\hline Talas bölgesi & 39 & 17 & 213 & 24 & 2 & 2 & 297 \\
\hline Çüy bölgesi & 104 & 47 & 810 & 269 & 15 & 2 & 1247 \\
\hline Bişkek şehri & 453 & 193 & 1,968 & 2,729 & 29 & - & 5372 \\
\hline Oş şehri & 103 & 25 & 232 & 451 & 5 & - & 816 \\
\hline
\end{tabular}

Kaynak: KC Milli İstatistik Komitesi. Сборник Туризм в Кыргызстане 2014-2018.

Kırgızistan'daki turizm işletmelerinin önemli kısmı Bişkek şehri ve Isık-Göl bölgesinde bulunmaktadır (Tablo 3). Turizmden elde edilen gelirin yaklaşık \% 90'nı Isık Göl destinasyonu sağlamasının yanı sıra Isık Göl'ün en büyük problemi sezonun kısa olmasıdır (Jenish, 2017:21). Y1l boyunca Isık-Göl'ü ziyaret eden turistlerin \% 90'1 Temmuz ve Ağustos aylarında gelirken, geri kalanı ise diğer 10 ayda ziyaret etmektedirler.

\section{Kırgızistan Turizmi Durum Tespiti ile İlgili Çalışmalar}

- Gülcan ve arkadaşları (2014), Kırgızistan'ın güneyindeki binlerce yıllık tarihi geçmişe sahip Oş şehrinde bulunan ve şehrin simgesi haline gelen, UNESCO'nun Dünya Kültür Mirası listesine de giren, Süleyman Dağı'nın ülkedeki din ve kültür turizm açısından SWOT analizini yapmışlardır. Çalışmada araştırma yöntemi olarak genel tarama modeli seçilmiştir, diğer bir ifadeyle SWOT analizinde literatür taraması ve ikincil verilerden yararlanılmıştır. Süleyman Dağının Oş şehrine kültür ve inanç turizmi açısından çekicilik merkezi olmasına yaptığı katkılara dikkat çekilmiş, turizm politika ve planlamalarının yetersizliği, yerli halkının bilinçsizliği ve bazı kaya resimlerinin tahrip edilmesi gibi problemler dile getirilmiştir.

- Kırgızistan'ın iç ve dış turizmin merkezi olan Isık-Göl bölgesinin turizm sektörü açısından SWOT analizi Эралиева (2015) tarafından yapılmıştır. Söz konusu çalışmada literatür taraması ve ikincil veriler kullanılmıştır. Araştırmaya ait sonuçlar aşağıda ki Tablo 4'te yer almaktadır.

Tablo 4: Isık-Göl'ün Turizm Sektörü Açısından SWOT Analizi

\begin{tabular}{|c|c|}
\hline $\begin{array}{l}\text { Güçlü Yönleri } \\
\text { - } \quad \text { Coğrafi konum; } \\
\text { - } \quad \text { Turizm tesisleri mevcut; } \\
\text { - } \quad \text { Isık-Gölün kendisi, doğası } \\
\text { - } \quad \text { Tarımın gelişmesi }\end{array}$ & $\begin{array}{l}\text { Zayıf Yönleri } \\
\text { - Ulaşım hizmetlerin yeterli gelişmemesi } \\
\text { - Turizm hizmetlerinin yetersizliği } \\
\text { - Şehir alt ve üst yapısının yetersizliği Şehir bütçesinin } \\
\text { sinırlı olması }\end{array}$ \\
\hline $\begin{array}{l}\text { Fırsatlar } \\
\text { - Ulaşım hizmetlerine yatırım } \\
\text { - Tarihi-kültürel mirasa ilginin artması } \\
\text { - Alt ve üst yapının geliştirilmesi } \\
\text { - } \quad \text { Ekoloji güvenliğinin artırılması }\end{array}$ & $\begin{array}{l}\text { Tehditler } \\
\text { - Yatırımların yetersizliği } \\
\text { - Devlet desteğinin yetersizliği } \\
\text { - Etkin olmayan turizm politikası ve yönetimi } \\
\text { - Turizm mevzuatının tam olmayışı }\end{array}$ \\
\hline
\end{tabular}

Kaynak: Eralieva (2015),

- Дыйканов (2019) ise, Kırgızistan'ın güneyinde yer alan Batken bölgesinin turizm potansiyelini ve sorunlarını incelemiştir. Çalışmada Batken bölgesinde kültür turizmi, yayla turizmi, sağlık turizmi açısından sanatoryum ve kaplıcalar, dağ turizmi için zirveler ve kanyonlar, ayrıca da Kırgızistan'daki en büyük mağaraları ile alternatif turizmi potansiyeline dikkat çekilmiştir. Tüm bu avantajlara rağmen turist 
A. Tayfun - E. Akgöz - N. Margazieva - K. Asanova 12/1 (2020) 693-704

ağırlamada ciddi sorunlar yaratacak zorlukların olduğu belirtilmiştir. Batken bölgesinin en başta gelen sorunlarından Tacikistan ve Kırgızistan arasında sınır ile ilgili sorunları, karayolların kötülüğü, konaklama işletmelerinin sayı ve hizmet kalitesi açısından yetersizliği gibi bir takım olumsuzluklar da bu çalışmada dikkat çekilmiştir.

- Jenish (2017) "Tourism Sector in Kyrgyzstan: Trends and Challenges" (Kırgizistan'da Turizm Sektörü: Eğilimler ve Zorluklar) isimli çalışmasında ülke turizminin sahip olduğu güçlü yönleri ve mevcut problemleri ortaya koymaya çalışmıştır. Jenish'e göre, Kırgızistan'ın turizmi şu üç değer zincirinden oluşmaktadır:

1. Isık-Göl sahil (3S, Sea, sun, sand) turizmi;

2. Kültür turizmi ve eko-turizminin yanısıra 'yumuşak' macera turizmi;

3. Ekstrem sporlar ve aşırı macera turizmi.

Bu unsurlar turizmden elde edilen gelirlerin büyük bir kısmını oluşturmakla birlikte Kırgızistan'daki geniş turizm faaliyetlerinin yelpazesini de ortaya koymaktadır.

Jenish (2017) tarafından gerçekleştirilen araştırmaya göre Kırgızistan turizmi ile ilgili mevcut zorlukları da şu şekilde sıralamıştır:

- Erişim zorluğu, altyapı ve üst yapının yetersizliği

- Zayıf pazarlama ve dijital teknolojilerin yetersiz kullanımı

- Hizmetlerin kalitesizliği ve hizmet sağlayıcılarının eksiklikleri

- Turizm sezonunun kisa olmasi

- Turizm işletmesi kurmak ve işletmek için karşılaşılan idari engeller

- Turizm gelir dağılımının eşit olmaması

- Bilinçsiz kaynak kullanımı ve çevre kirliliği

- Son olarak da K.C. Kültür, Enformasyon ve Turizm Bakanlığı tarafından hazırlanan 2019-2023 Sürdürülebilir Turizmi Geliştirme Planında Kırgızistan'da sürdürülebilir turizmin sağlayacağ fırsatlar şu şekilde belirtilmektedir:

- Sürdürülebilir turizm bilincinin yaygınlaşması ile sosyal, kültürel, çevresel ve ekonomik sorunların fark edilmesi,

- Dünya halklarının yakınlaşması, Kırgızistan'ın zengin kültürel değerlerinin ve ulusal kimliğin korunmasına katkıda bulunması,

- Turizm gelişimi ile birlikte doğal kaynakların en iyi şekilde kullanılması,

- Sürdürülebilir turizm anlayışı ile yerel halka istihdam fırsatlarının sağlanması sonucunda bölge halkının ekonomik açıdan güçlenmesi ve yoksulluğun azaltılmasına katkıda bulunmasıdır.

Süründürülebilir Turizm Gelişimi Programında Kırgızistan turizmi ile ilgili sorunlar ise şu şekilde sıralanmaktadır:

- Turizm ve rekreasyon alanlarındaki altyapı yetersizliği

- Popüler turistik destinasyonlarındaki karayolları hizmet kalitesinin düşük olması

- Turizm altyapısı için kamu yatırımlarının arzu edilen düzeyde olmaması

- Devlet organlarında turizm altyapısı hakkında ki bilgi eksikliği;

- Yabancı dillerde coğrafik işaret ve levhaların olmaması

- Turizm destinasyonları ve turistik rotalara ait navigasyon, GPS vb. sistemlerin yokluğu

- Uluslararasi standartlara uygun konaklama tesisleri ve kongre merkezlerinin olmamasi

- Kırgızistan'ı ana turizm pazarlarına direk bağlayan hava yollarının yetersizliği

- Havaalanında yolcu hizmetleri, kuyruklar, bagaj gecikmesi, taksi hizmetleri gibi problemler

- Pasaport, vize ve sınır geçişlerindeki bürokratik engeller

- Turizm sektöründe kalifiye personel istidam edilmemesi

- Koruma altına alınmış doğal alanlarda turistik rotaların hazırlanmaması

Herhangi bir ülkenin turizminden söz edilebilmesi için yeterli turizm arzına sahip olması gerekmektedir. Turizm arzı, herhangi bir destinasyona gelen misafirlerin yararlanması için sunulan her türlü doğal, tarihî, kültürel, arkeolojik değerlerle tesis ve hizmetlerin tamamıdır (Akgöz vd., 2018: 16). Genel olarak turizm arzını iki şekilde değerlendirmek mümkündür. Birincisi destinasyonun sahip olduğu tüm doğal, tarihi ve diğer turistik kaynaklarından oluşur. İkincisi ise, turistlerin seyahat etmelerine ve tatil yapmalarını mümkün kılan 
A. Tayfun - E. Akgöz - N. Margazieva - K. Asanova 12/1 (2020) 693-704

turistik hizmetlerinden oluşmaktadır (Cengiz, 2012: 23). Kısaca turizm arzı; bir ülke, bölge veya yörenin belli bir dönemde belli şartlar altında turistlere satmaya razı olduğu turistik zenginliklerin tamamı şeklinde tanımlanabilir (Ünlüönen vd. 2018). Kırgızistan'ın Turizm arzını Dudaşvili şu şekilde sınıflandırmıştır (Дудашвили, (2004: 37):

\section{Kırgızistan Cumhuriyeti'nin Turistik Arzı}

\begin{tabular}{|l|}
\hline Doğal Unsurlar \\
\hline \begin{tabular}{l} 
Coğrafi Özellikler \\
Mağlar ve Buzullar \\
Göller ve Nehirler \\
Yaylalar \\
\hline
\end{tabular} \\
\hline Biyoçeşitlilik \\
\hline Fauna \\
Flora \\
Endemik bitki \\
Koruma altında olan \\
hayvanlar \\
\hline \\
\hline Ekosistem \\
\hline İklimsel faktörler \\
Ilıca, Kaplıca, çamur \\
Kurortlar \\
Vahşi Doğa \\
Milli parklar \\
\hline
\end{tabular}

\begin{tabular}{|l|}
\hline Sosyo-Kültürel Unsurlar \\
\hline Sosyo-Politik Durumu \\
\hline Ülke imajı \\
Misafirperverliği \\
Demokratik Anayasa \\
İki Resmi dil \\
İpek Yolu İsbirliği anlaşması \\
\hline Tarihi ve Mimari Eserler \\
\hline Tarihi eserler \\
İpek Yolu üzerinde yer alan \\
değerler \\
Modern Mimari yapılar \\
Dini eserler \\
\hline \\
\hline Kırgızistan'ın etnografik değerleri \\
\hline Bozüy \\
Halk Oyunları, \\
Örf Adetler \\
El Sanatları \\
Geleneksel kıyafetler \\
Yöresel yemekler \\
Manas Destanı \\
C. Aytmatov \\
\hline
\end{tabular}

2019-2023 sürdürülebilir Turizm Geliştirme Programında yer alan Kırgızistan'ın öncelikli doğal ve tarihikültürel turizm destinasyonlarının haritası:

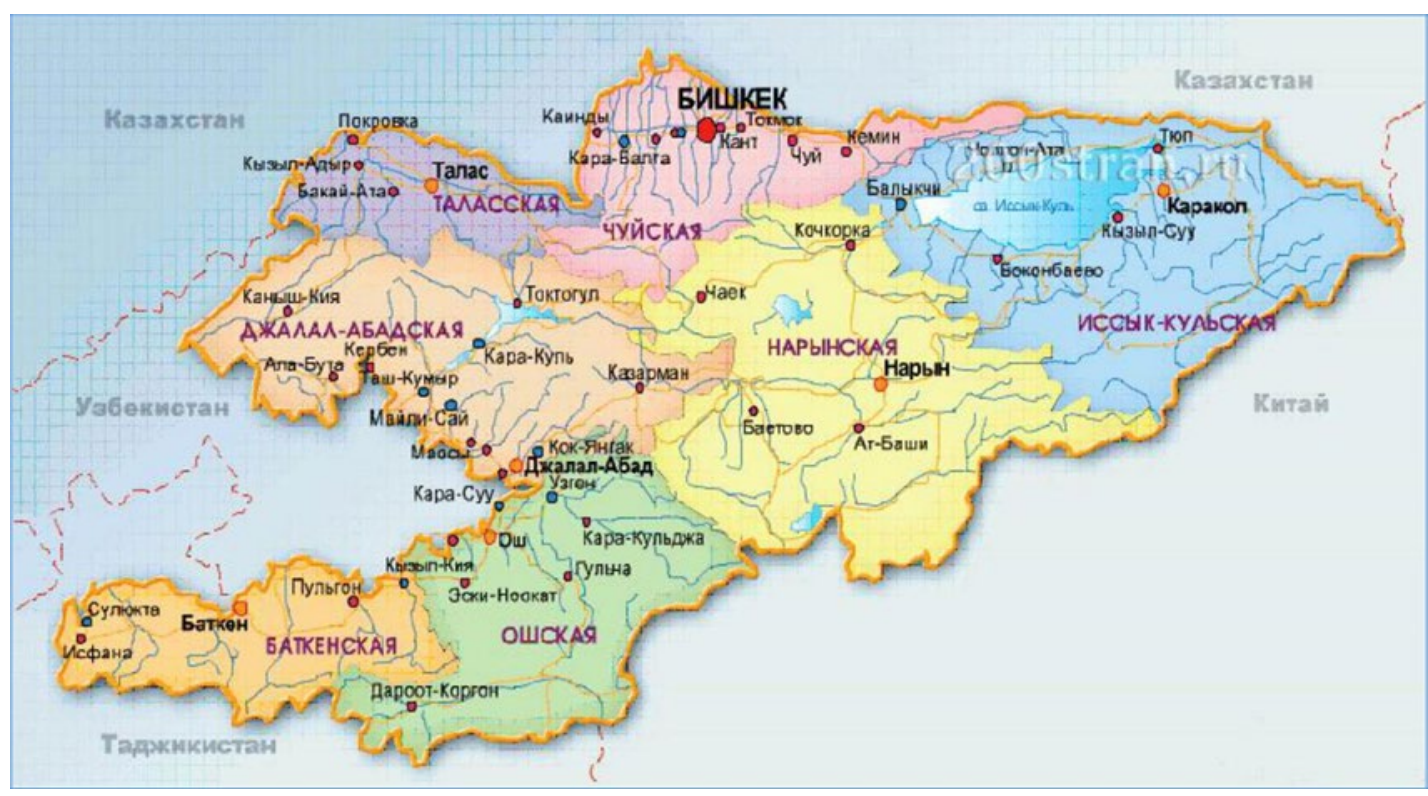

1. Burana Tarihi ve Kültürel Kompleksi "Burana Kulesi";

2. Krasnoreçinskoe Kenti;

3. "Ak-Beşim" Kenti; 
4. Isık- Gölün Kuzey Kıyısındaki Kaya Resimleri;

5. San-Taş Mezarlığı;

6. "Skazka" Kanyonu;

7. "Mancil1-Ata" Kutsal Yeri

8. Ölü Göl;

9. "Taş Rabat";

10. Kök-Taş Mezarlığı;

11. Son Göl;

12. "Ala-Arça" Milli Parkı

13. "Süleyman-Too" Tarihi, Kültürel ve Doğal Müzesi;

14. "Özgön" Tarihi Ve Kültürel Kompleksi

15. "Şah Fazil Tarihi Ve Kültürel Kompleksi," Şah-Fazil " Türbesi;

16. "Arslan-Bob" Türbesi;

17. Sarı-Çelek Doğa Koruma Alanı;

18. 'İdris Paygambar' Gumbezi;

19. "Manas-Ordo "Milli Kırgız Tarihi ve Kültürel Kompleksi

\section{Evren Örneklem}

Bir araştırmada, ilgili alanda bilgi alınabilecek veya fikir edinilebilecek niteliğe sahip her birey ya da varlığın oluşturduğu topluluk evren olarak nitelendirilir. Evren içindeki her birey örnek olarak adlandırılırken, tüm evreni temsil edebilecek nitelikteki örnek sayısının seçilmesi işlemine de örneklem adı verilmektedir (Büyüköztürk, 2002). Bu araştırmanın evreni ise Kırgızistan turizmi ile ilgili kamu çalışanları, özel sektör temsilcileri, akademisyenler ve turizm alanında eğitim alan yüksek lisans öğrencileridir. Evreni temsil edeceği varsayılan 15 özel sektör temsilcisi, 8 kamu çalışanı (tam sayım), 16 akademisyen (Kırgızistan Türkiye Manas Üniversitesi (KTMÜ)) (tam sayım), 12 yüksek lisans öğrencisinin (KTMÜ) (tam sayım) görüşleri alınmıştır.

\section{Veri Toplama Tekniği}

Araştırmada veri toplama yöntemi olarak nicel araştırma yönteminden anket yöntemine başvurulmuştur. Öncelikle, anketin şekillendirilmesi için, literatürde araştırma konusuna benzer ya da yapısal olarak yakın çalışmalar taranmıştır. Daha sonra anketin şekillendirilmesi amacıyla, Kırgız turizmi ile ilgili kamu çalışanları, özel sektör çalışanları, akademisyenler ve öğrencilerin görüşleri alınarak ankete son şekli verilmiştir. Anket formunda turizm işletmeleri için Kırgızistan turizminin güçlü, zayıf yönleri ile gelecekte oluşabilecek fırsat ve tehditlerin tespitine yönelik sorulara yer verilmiştir. Beşli likert ölçeğine uygun olarak hazırlanan anket formunda verilen ifadelere 1 ile 5 (5-Tamamen Katılıyorum 1- Hiç Katılmıyorum) arasında bir puan vermeleri istenmiştir.

\section{Bulgular Ve Yorumlar}

Araştırmaya ait bulgular beş ana tabloda değerlendirilmiştir. Birinci tabloda turizm işletmeleri için potansiyele yönelik genel yapı ortaya konulmuştur. Diğer dört tabloda ise Kırgızistan'ın güçlü, zayıf yönleri ile ileriye dönük fırsat ve tehditler ayrı ayrı derinlemesine analiz edilmiştir.

Tablo 5: Kırgizistan Turizminin SWOT Analizi

\begin{tabular}{|l|c|l|c|}
\hline \multicolumn{1}{|c|}{ Güçlü } & $\overline{\mathbf{x}}$ & \multicolumn{1}{c|}{ Zayıf } & \multicolumn{1}{c|}{$\mathbf{x}$} \\
\hline Geleneksel konuk severlik & 4,63 & Alt yapı yeterli değil & 4,24 \\
\hline Kış turizmi imkânları & 4,57 & Temizlik ve hijyen sorunları & 4,06 \\
\hline Coğrafi konum & 4,14 & Yerel yönetimin isteksizliği & 3,92 \\
\hline El sanatları ve ürün çeşitliliği & 4,02 & Tanıtımda internetin kullanılmaması & 3,92 \\
\hline Yerel mutfak ürünleri & 3,90 & Devlet-sektör çatışması & 3,90 \\
\hline Tarihi değerler & 3,84 & Turizm enformasyon bürolarının olmaması & 3,88 \\
\hline Yerel halkın gelenekleri sürdürmesi & 3,71 & Turizm için kalifiye personel eksikliği & 3,86 \\
\hline Girişimcilerin turizme destek olması & 3,59 & $\begin{array}{l}\text { Ülkeyi tanıtan tabela, harita ve tanıtım levhalarının } \\
\text { yetersizlikleri }\end{array}$ & 3,84 \\
\hline \multicolumn{1}{|c|}{ Firsat } & $\overline{\mathbf{x}}$ & & $\mathbf{x}$ \\
\hline
\end{tabular}


A. Tayfun - E. Akgöz - N. Margazieva - K. Asanova 12/1 (2020) 693-704

\begin{tabular}{|l|r|l|l|}
\hline Bakir doğal yapısı & 4,47 & Doğal kaynakların ve çevrenin tahrip olması & 4,53 \\
\hline Alternatif turizm imkânları & 4,43 & Uluslararası siyasi belirsizlikler & 4,20 \\
\hline Komşu ülkelerdeki turizm gelişmeleri & 4,35 & Halkta turizm bilincinin olmaması & 4,12 \\
\hline Turizmin öncelikli sektör olması & 4,35 & Ülkedeki siyasi belirsizlikler & 4,10 \\
\hline $\begin{array}{l}\text { Ziyaret edilmesi gereken destinasyonlar listesinde } \\
\text { yer alması }\end{array}$ & 4,35 & Sürdürülebilir bir turizm planlamasının olmaması & 4,00 \\
\hline Ülkeye vizesiz giriş imkânı & 4,31 & Turizm konusunda uzman kişilerin olmaması & 3,96 \\
\hline Dünya turizm hareketlerindeki gelişmeler & 4,31 & Turist güvenliğinin yetersizliği & 3,92 \\
\hline Yatırım çekebilme potansiyeli & 4,18 & $\begin{array}{l}\text { Çalışabilir nüfusun önemli kısmının yurtdışına } \\
\text { yöneliyor olması }\end{array}$ & 3,84 \\
\hline
\end{tabular}

Tablo 5 incelendiğinde ülkenin güçlü yönü olarak; geleneksel konukseverlik, kış turizmi imkânları ve coğrafi konumu ön plana çıkmaktadır. Zayıf yön olarak alt yapı yetersizliği, temizlik ve hijyen sorunları, yerel yönetimlerin isteksizliği gibi unsurlar ilk üç sırayı aldığı anlaşılmaktadır. Fırsat olarak bakir doğal yapı, alternatif turizm imkânları, komşu ülkelerdeki turizm gelişmelerin olduğu görülmektedir. Doğal kaynakların ve çevrenin tahrip olması, uluslararası siyasi belirsizlikler, halkta turizm bilincinin olmaması gibi unsurlarda tehdit olabileceği dikkat çekilmektedir.

Tablo 6: Araştırmaya Katılanların Kırgızistan Turizminin Güçlü Yönlerine Dair Değerlendirmeleri

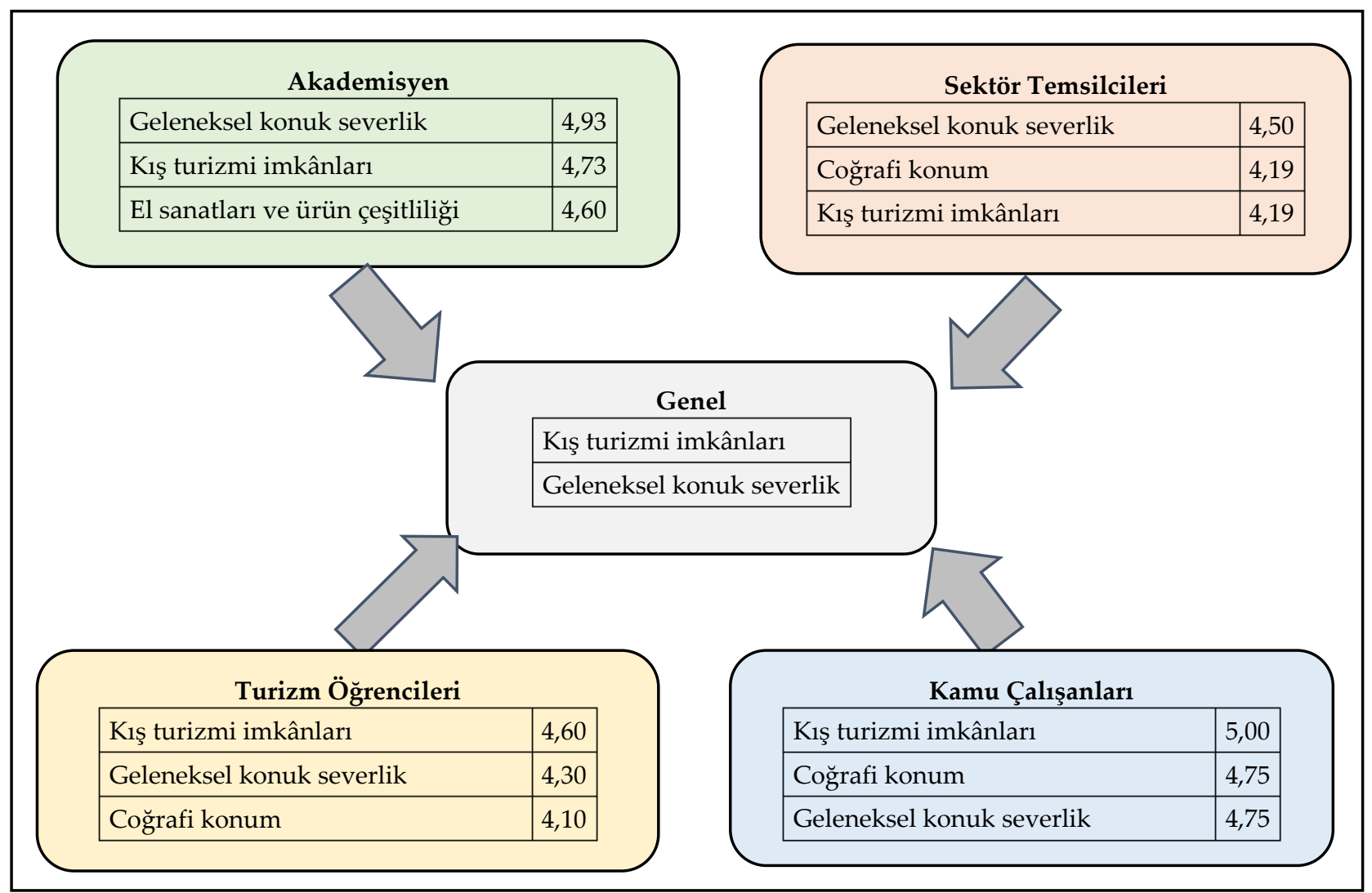

Tablo 6 da araştırmaya dahil edilen akademisyen, sektör, öğrenci ve kamu çalışanlarının turizm sektöründe faaliyet gösteren işletmeler açısından Kırgızistan turizminin güçlü yönlerine ait değerlendirmelerine yer verilmiştir. Tablo incelendiğinde dört tarafında güçlü yön olarak ülkenin sahip olduğu kış turizmi imkânları ve geleneksel konukseverlik konusunda ayn fikirde oldukları görülmektedir. 
A. Tayfun - E. Akgöz - N. Margazieva - K. Asanova 12/1 (2020) 693-704

Tablo 7: Araştırmaya Katılanların Kırgızistan Turizminin Zayıf Yönlerine Dair Değerlendirmeleri

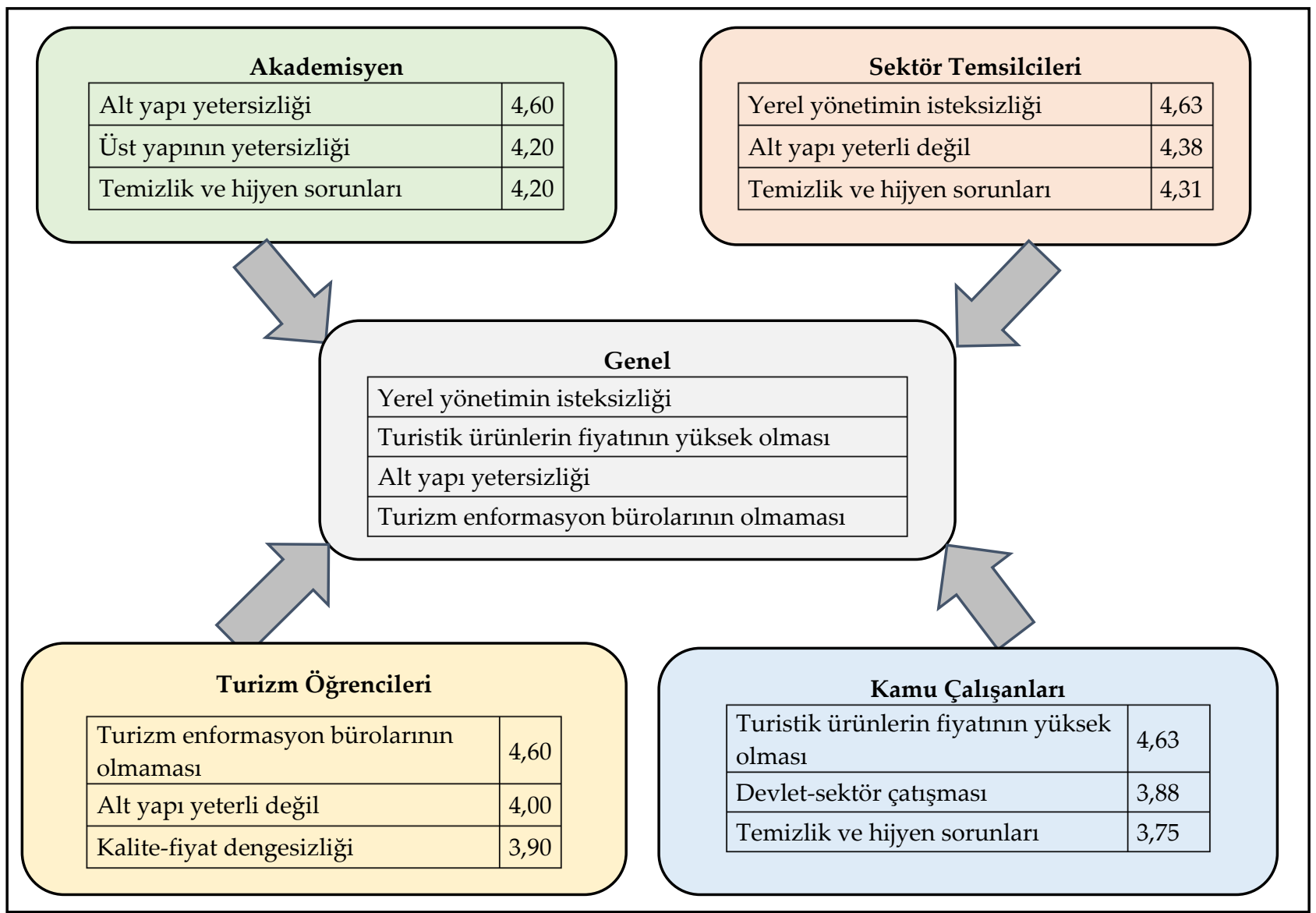

Tablo 7 de Kırgızistan' da faaliyet gösteren işletmeler için turizm konusundaki zayıf noktalara yer verilmiştir. Bunun için de araştırma kapsamında yer alan akademisyen, sektör temsilcisi, öğrenci ve kamu çalışanlarının görüşleri dikkate alınmıştır. Tablo incelendiğinde turizm konusunda düşünceleri alınan her kesimin Kırgızistan'ın turizm ile ilgili olumsuzluklar hakkında farklı değerlendirmelere sahip oldukları görülmektedir.

Tablo 8: Araştırmaya Katılanların Kırgızistan Turizmine Dair Fırsat Değerlendirmeleri

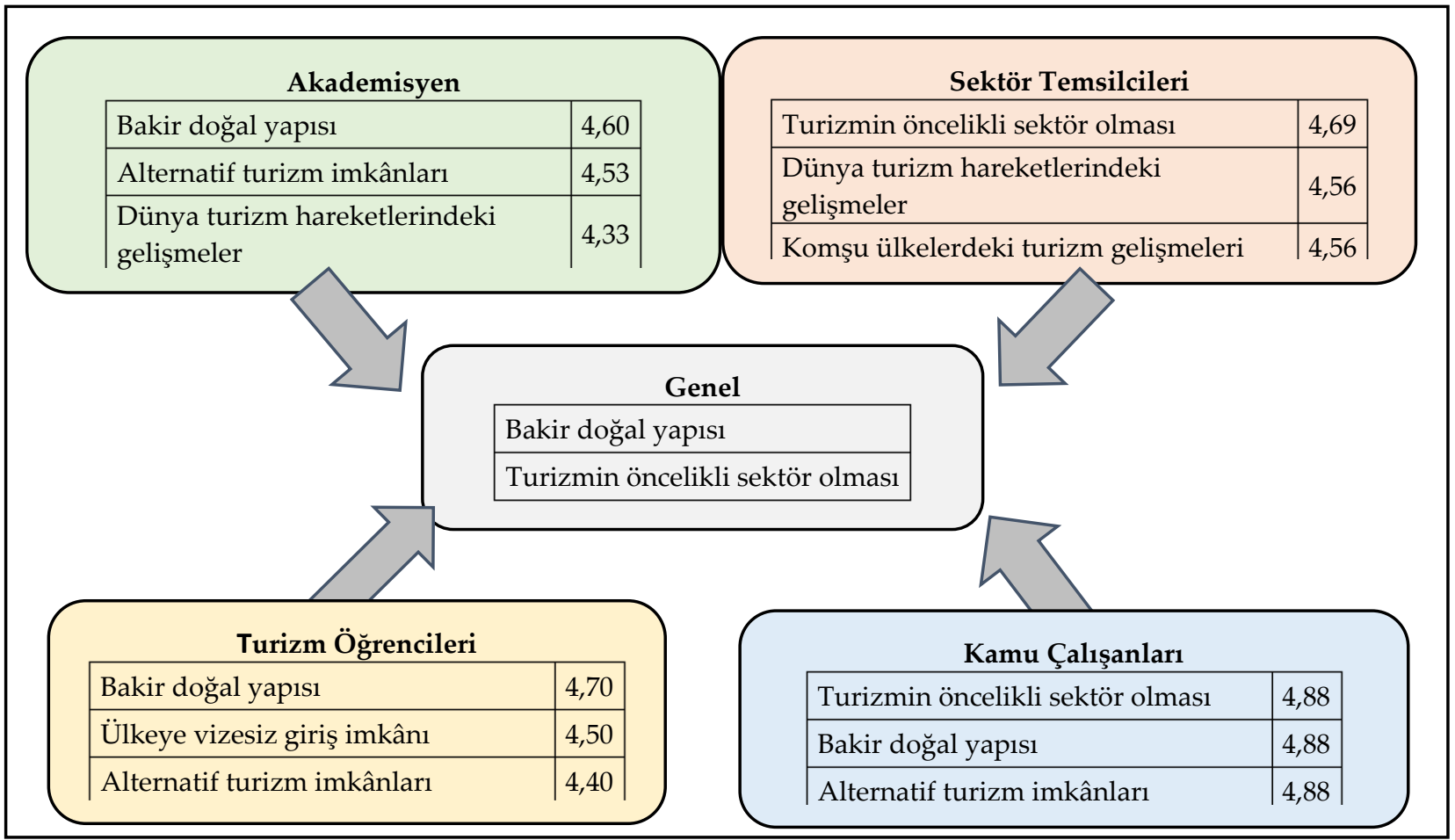


A. Tayfun - E. Akgöz - N. Margazieva - K. Asanova 12/1 (2020) 693-704

Araştırmaya katılanların Kırgızistan turizmine ait fırsat değerlendirmeleri Tablo 8 de verilmiştir. Tablo incelendiğinde fırsatlar ile ilgili görüş belirten dört farklı kesim de işletmeler için Kırgızistan'ın sahip olduğu bakir doğal yapı ve turizmin öncelikli sektör olması konusunda hem fikir oldukları görülmektedir.

Tablo 9: Araştırmaya Katılanların Kırgızistan Turizmine Dair Tehdit Değerlendirmeleri



Tablo 9 da araştırmaya dahil edilen akademisyen, öğrenci, sektör temsilcisi ve kamu çalışanlarının Kırgızistan faaliyet gösteren turizm işletmelerine yönelik tehditleri değerlendirmelerine yer verilmiştir. Tablo incelendiğinde akademisyen ve kamu çalışanlarının aynı tehditler konusunda aynı görüşte oldukları, öğrenci ve sektör temsilcilerinin ise farklı değerlendirmeler yaptıkları görülmektedir.

\section{Sonuç ve Öneriler}

Kırgızistan gibi gelişmekte olan ülkeler için avantajlı sektörlerden biri turizmdir. Çünkü turizm ile birlikte 21 değişik sektör ve 47 iş kolu da gelişebilmektedir (Yıldız, 2011). Bu özelliğinden dolayı özellikle turizm sektörüne yönelik faaliyet gösteren işletmeler için turizm potansiyelinin doğru tespit edilmesi, etkin planlamaların yapılması ve kaynakların doğru kullanılması gerekmektedir. Bu çalışma, işletmeler için Kırgızistan turizminin güçlü ve zayıf yönleri belirlemek, fırsatlar ile tehditleri ortaya koymak için hazırlanmıştır.

Araştırma sonucunda akademisyenler ile sektör temsilcilerine göre "Geleneksel konuk severlik" Kırgızistan turizminin en önemli potansiyeli olduğu anlaşılmaktadır. Turizm öğrencileri ile kamu çalışanları ise Kırgızistan turizmi için en avantajlı unsurun "Kış turizmi imkânları" olduğunu belirtmektedirler. Kırgızistan'ın el sanatları ve ürün çeşitliği sadece akademisyenler tarafından ilk sırada değerlendirilirken, diğer katılımcılar "Coğrafi konumu" Kırgızistan turizminin güçlü yönü olarak kabul etmektedirler. Araştırma kapsamında görüş belirtenler, Kırgızistan'da faaliyet gösteren turizm işletmeler için "Kış turizmi imkânları" ile "Geleneksel konukseverlik" en güçlü iki özellik olduğuna dikkat çekmektedirler.

Kırgızistan turizminin zayıf yönleri ile ilgili düşünceler de ise araştırmaya katılanlar arasında net bir fikir birliği sağlanamamıştır. Akademisyenler "Alt yapı yetersizliği", sektör temsilcileri "yerel yönetimin isteksizliği", turizm öğrencileri "Turizm enformasyon bürolarının olmaması", kamu çalışanları da "Turistik ürünlerin fiyatının 
A. Tayfun - E. Akgöz - N. Margazieva - K. Asanova 12/1 (2020) 693-704

yüksek olması" gibi unsurları Kırgızistan turizminin zayıf yönü olarak belirtmektedirler. "Alt yapı yetersizliği" kamu çalışanları hariç tüm paydaşlar tarafından turizmin gelişmesi için önemli engel olarak kabul edilmektedir.

Araştırma kapsamında elde edilen verilere göre Kırgızistan'da faaliyet gösteren ve/veya faaliyet göstermeyi planlayan turizm işletmeler için en önemli fırsat olarak "Bakir doğal yapısı" ile "Turizmin öncelikli sektör olması" olduğu anlaşılmaktadır. Ayrıca "Dünya turizm hareketlerindeki gelişmeler" ve "Alternatif turizm imkânları" gibi unsurlar da önemli fırsatlardandır. Turizm işletmeleri için tehdit olarak kabul edilen unsurlar konusunda ise tam bir görüş birliği sağlanamamıştır. Akademisyenler ile kamu çalışanları "Doğal kaynakların ve çevrenin tahrip olması", sektör temsilcileri "Ülkedeki siyasi belirsizlikler", turizm öğrencileri de "Sürdürülebilir turizm planlamasının olmamasını" Kırgızistan turizmi için en büyük tehdit olarak kabul etmektedirler.

Kırgızistan tarihi ve kültürel değerleri, doğal güzellikleri ve alternatif turizm türleri ile turizme yönelik hizmet sunan/sunmayı planlayan işletmeler için önemli bir potansiyele sahiptir. Girişimcilerin devlet desteği beklemeksizin turizm sektörüne yönelik yatırımlar gerçekleştirmesi, Kırgızistan turizmi için önemli bir avantaj oluşturmaktadır. Alt yapı hizmetlerinin iyileştirilmesi, temizlik ve hijyen konularına daha fazla ağırlık verilmesi, etkin tanıtım ve pazarlama faaliyetlerinin yapılması işletmeler açısından turizmden arzu edilen sonuçların alınmasına yardımcı olacaktır. Ayrıca bakir doğal alanların korunması, alternatif turizm türlerinin geliştirilmesi, bir takım bürokratik engellerin kaldırılması da Kırgızistan'da faaliyet gösteren işletmeler için önemli fırsatlar oluşturacaktır. Tüm bunlar gerçekleştirilirken halkın turizm konusunda bilinçlendirilmesi, turist güvenliğinin sağlanması, muhtemel siyasi belirsizliklerin giderilmesi ve uluslararası gelişmelerin yakından takip edilmesinin de turizm işletmelerinin hedeflerine ulaşabilmesi, ülke ekonomisine katkı sağlayabilmesi açısından büyük bir önem arz ettiği düşünülmektedir.

\section{Kaynakça}

Akgöz, E. B. Erdem, T.Gök, C. İnce, U.Alimov, N.Turganbaeva, K. Asanova. (2018). Kırgızistan'da Konaklama İşletmelerinin Sınıflandırllması ile İlgili Bir Model Önerisi. BYR Publishing House, Bişkek. (Editör: Erkan Akgöz).

Büyüköztürk, Ş. (2002). Faktör Analizi: Temel Kavramlar ve Ölçek Geliştirmede Kullanımı. Kuram ve Uygulamada Ĕ̆itim Yönetimi Dergisi, 8(32), s. 470-483.

Cengiz, F. (2012). Üçüncü Yaş Turistlere Yönelik Turistlik Ürün Analizi: Alanya Uygulaması. Antalya Akdeniz Üniversitesi Sosyal Bilimler Enstitüsü, (Yayınlanmamış Doktora Tezi).

Дыйканов, К. (2019). Кыргызстандын Баткен аймагынын туризм потенциалы жана тоскооддуктары. III Эл аралык түрк дүйнөсу туризми симпозиуму, 20-22 апрель 2017. Бишкек, Кыргызстан.

Дудашвили. С.Д. (2004). Туристические ресурсы Кыргызстана. Раритет Инфо, Бишкек.

Эралиева, А. А. (2015). Комплексные аспекты геобрендинга Иссык-Кульской области. Брендинг малых и средних городов России: опыт, пр облемы, перспективы. Материалы междунар. науч.-практ. конф. г. Екатеринбург, 24 апреля . - Екатеринбург : Изд-во Урал. ун-та, с. 74-76.

Erdem, B., B. Gülcan, C.Tokmak, K.Asanova ve N. Margazieva. (2015). Kırgizistan Konaklama Sektöründe İnsan Kaynakları Profili Araştırması. Manas Sosyal Araştırmalar Dergisi. Cilt: 4 Sayı: 3.

Jenish, N. (2017). Tourism Sector in Kyrgyzstan: Trends and Challenges. Working paper \#42. Institute of Public Policy and Administration. University of Central Asia.

Gülcan, B., F. Şenol ve A. Aytpaeva. (2014). Kırgızistan'da Din ve Kültür Turizminin Geliştirilmesi Açısından Süleyman Dağı'nın Önemi: Swot Analizi. Manas Sosyal Araştırmalar Dergisi. Cilt: 3 Sayı:4.

KC Milli İstatistik Komitesi. (2019). Нацุиональный статистический комитет Кыргызской Республики. Туризм в Кыргызстане 2014-2018. Статистический сборник.

Kırgızistan Milli İstatistik Komitesi. (2018). Национальный статистический комитет Кыргыьзской Республики. Окружающая среда в Кыргызской Республике 2013-2017. Статистический сборник. 
A. Tayfun - E. Akgöz - N. Margazieva - K. Asanova 12/1 (2020) 693-704

Milli Çevre Raporu. (2016). Государственное агентство охраны окружающей среды и лесного хозяйства при Правительстве Кыргызской Республики. Национальный доклад о состоянии окружающей среды Кыргызской Республики за 2011-2014 годы. Одобрен распоряжением Правительства Кыргызской Республики от 19 декабря № 549-р.

Ünlüönen, Kurban; A. Tayfun: A. Kılıçlar (2018). Turizm Ekonomisi, Nobel Yayınevi, Ankara.

Yıldız, Z. (2011). Turizm Sektörünün Gelişimi ve İstihdam Üzerindeki Etkisi. Süleyman Demirel Üniversitesi Vizyoner Dergisi, 3(5), 54-71.

http://deptourism.gov.kg/программа-развития-туризма-до-2020-года/

https://dic.academic.ru/). 